\title{
L'agriculture d'Hésiode
}

\section{Charles Kanelopoulos}

\section{OpenEdition}

\section{Journals}

Édition électronique

URL : https://journals.openedition.org/tc/748

DOI : $10.4000 /$ tc. 748

ISSN : 1952-420X

\section{Éditeur}

Éditions de l'EHESS

\section{Édition imprimée}

Date de publication : 1 septembre 1991

ISSN : 0248-6016

\section{Référence électronique}

Charles Kanelopoulos, «L'agriculture d'Hésiode », Techniques \& Culture [En ligne], 15 | 1991, mis en ligne le 12 janvier 2006, consulté le 29 septembre 2022. URL : http://journals.openedition.org/tc/748 ; DOl : https://doi.org/10.4000/tc.748

Ce document a été généré automatiquement le 29 septembre 2022

Tous droits réservés 


\section{L'agriculture d'Hésiode}

Charles Kanelopoulos 